\title{
Accessibility of B-mode Ultrasonic Measurement of Subcutaneous Fat Thickness to the 22 Sites Needed for Clothing Design
}

\author{
Yoko MATSUYAMA ${ }^{1)}$, Momoko UETAKE ${ }^{2)}$, Minako KAKIUCHI ${ }^{1)}$, \\ Tanemi UETAKE ${ }^{1)}$, Sumiko YANAGISAWA ${ }^{1)}$ and Shiro KONDO ${ }^{2)}$ \\ 1) Faculty of Home Economics, Otsuma Women's University \\ 2) Institute of Human Living Sciences, Otsuma Women's University
}

\begin{abstract}
Information about subcutaneous fat distribution over the entire body is 'important for clothing design as applied anthropology. The measurement of subcutaneous fat thickness by ultrasonic tomogram overcomes the limitations of skinfold calipers measurement, but its accessibility varies depending on easiness of identifying the fat-muscle interface at the measuring sites. This study examined accessibility of ultrasonic tomograms at 22 body sites in 58 young adult females. Individual differences in the tomographic image at such sites as the triceps, plural echoes from the fat layer at such sites as the trochanter, and the "dead time region" at such sites as the wrist, make the identification difficult. The 22 sites were classified into three groups according to their accessibility to measurement. Seventeen sites were confirmed to be measurable, including the sites such as the buttock and thigh which are indispensable to the study of the apparent characteristics of the human body and obesity/leanness as a basis for the designing of comfortable clothing. The sites such as posterior neck and posterior sulcus were not considered to be accessible.
\end{abstract}

Keywords Subcutaneous fat thickness, B-mode ultrasonic method, Accessibility, Body sites, Clothing design

\section{Introduction}

The distribution of subcutaneous fat governs the apparent characteristic of the human body and seems to influence the intensity of the sense of garment pressure (MATSUYAMA et al., 1987), the key points of garment comfort. Thus, thickness and the patterning of subcutaneous fat are important data for clothing design as applied anthropology. The measurement of subcutaneous fat thickness for this purpose require covering the whole of the body. Several methods so far applied, however, have certain limitations or problems. In the skinfold measurement, which is the most widespread method and is recognized as providing a result highly correlated with relative body fat (NAGAMINE, 1972), it is difficult to form a complete fold on an obese and stiff body, and the reading accuracy of the calipers changes depending on the degree of compression of the measuring sites, which varies with sex, age or site (HIMES et al., 1979; KUCZMAR- 
SKI et al., 1987). The use of X-rays or advanced technology, including computed tomography, is still restricted to laboratory and clinical use.

The ultrasonic method is an uncompressed measurement, and is thus free from some limitations such as pain and so on. Within the category of ultrasonic techniques, there are two types of method (Fig. 1), namely, the A-mode (amplitude) and the B-mode (brightness). Because of the earlier development of instruments for the Amode, this was the method first used for thickness measurement. (HAYMES et al., 1982; KATCH, 1984; TOYOKAWA, 1984a, b; JONES et al., 1986). Studies using the B-mode are still relatively few. KATSUKI et al. (1965) developed a sectioning method for the B-mode, and dealt with the extremities of the body to examine body composition. The same method was used by IKAI and
FUKUNAGA $(1968,1969)$. Measurements by Bmode instruments for clinical use and by skinfold calipers have been correlated (MATSUMOTO

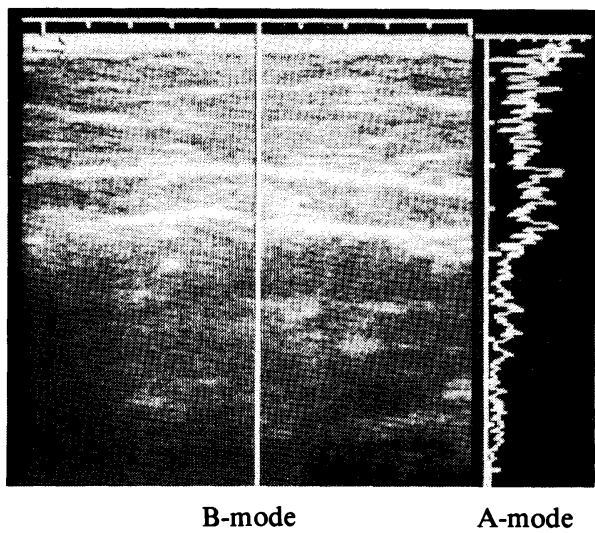

Fig. 1. Two kinds of ultrasonic graph of abdomen taken at the same time. The A-mode graph corresponds to the vertically lined part of the B-mode image.
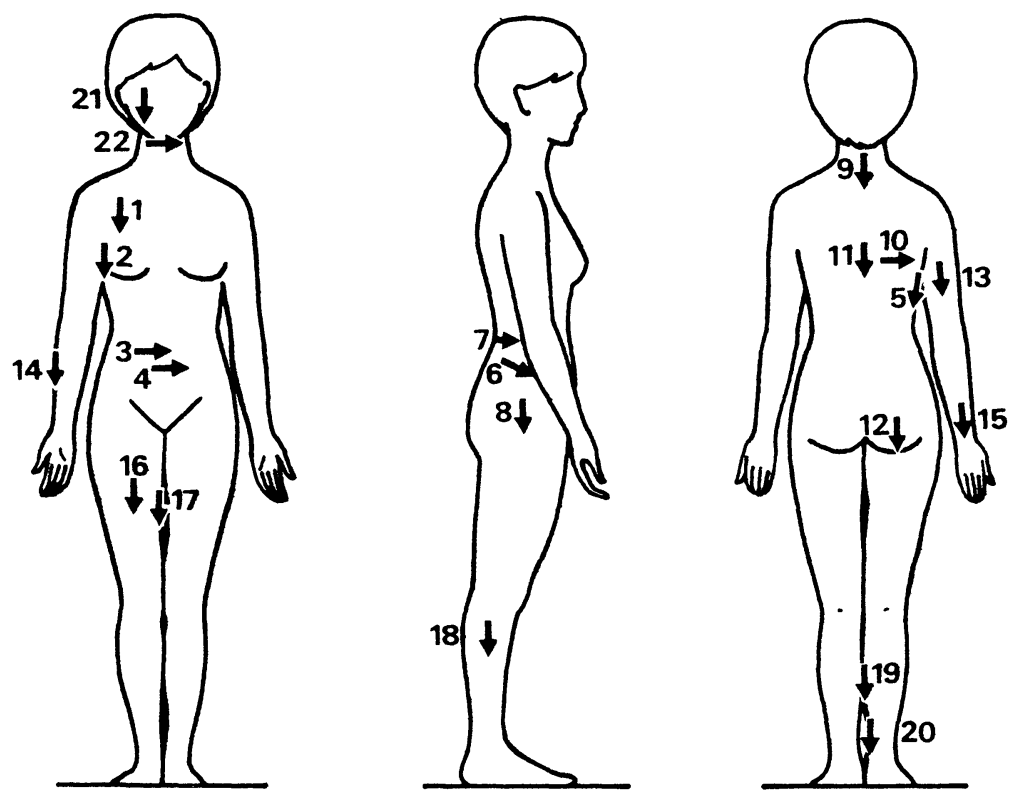

Fig. 2. Twenty two sites examined for accessibility in B-mode ultrasonic measurement of subcutaneous fat thickness. 1. anterior chest, 2. anterior axilla, 3. umbilicus, 4. abdomen, 5. lateral chest, 6. iliac crest, 7. posterior waist, 8 . trochanter, 9. posterior neck, 10. subscapular, 11. posterior sulcus, 12. buttock, 13. triceps, 14. lateral forearm, 15. wrist, 16. anterior thigh, 17. medial thigh, 18. lateral calf, 19. medial calf, 20. ankle, 21. cheek, 22. chin. The arrows indicate the standardized direction of the probe. 
et al., 1985) and further compared each other in predicting body density (FANELLI et al., 1981; KUCZMARSKI et al., 1987). The correlation coefficients reported from these investigations vary from 0.677 to 0.99 . Problems in the identification of the fat-muscle interface can arise in actual application, since it is not always easy to identify the waves correctly when individuals differ in the images (ISHII, 1986) and when ultrasonic waves reflect from some portions of the site other than fat-muscle interfaces. None of the previous investigations have reported on the identification of the boundaries of the fat layer at the sites needed for clothing design.

\section{Methods}

The apparatus used was an electronically scanning ultrasonic tomograph (Model EUB 26, Hitachi Medico). Probe frequency was 3.5 MHz. No stand-off was used. A tomogram was displayed on a cathode-ray tube and recorded by Polaroid photograph. Subcutaneous fat thickness was determined from the photograph to an accuracy of $0.1 \mathrm{~mm}$ using a digitizer connected to a personal computer. Compression with the probe was avoided at all sites

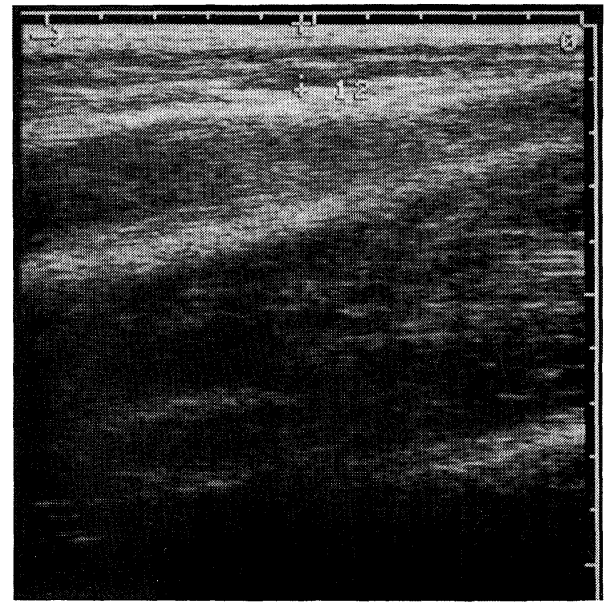

A with a caution not to press hard. The correlation coefficient of the ultrasonic values and values directly measured by a vernier calipers for pieces of fresh pork loin fixed in gelatin was 0.994 . The accessibility of B-mode ultrasonic measurement to the 22 sites (14 sites on the trunk including the head and 8 sites on the extremities, Fig. 2) was examined on the tomograms of 58 Japanese females aged from 21 to 26 years. The subjects did not show any noteworthy tendency to obesity/leanness.

\section{Results}

Problems in discriminating subcutaneous fat boundaries

The problems in discriminating subcutaneous fat boundaries were as follows:

1) Individual differences in the image of the layer: In the tomograms, the pattern of fat and other tissues sometimes varied between individual subjects, especially for subscapular, triceps (Fig. 3 ) and anterior thigh sites. Images of the medial calf and medial thigh, however, were similar in all the subjects. Generally, individual difference of pattern was greater for sites where muscle and tendon formed a complicated tangle.

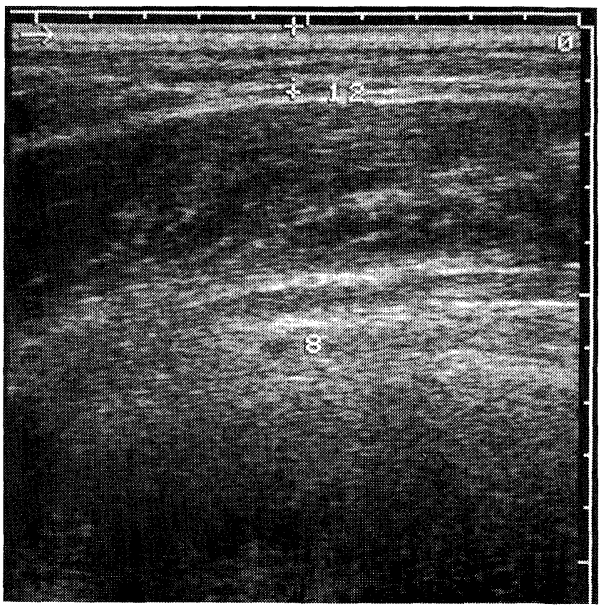

B

Fig. 3. Cases $A$ and $B$ show individual difference of pattern in image at triceps. 


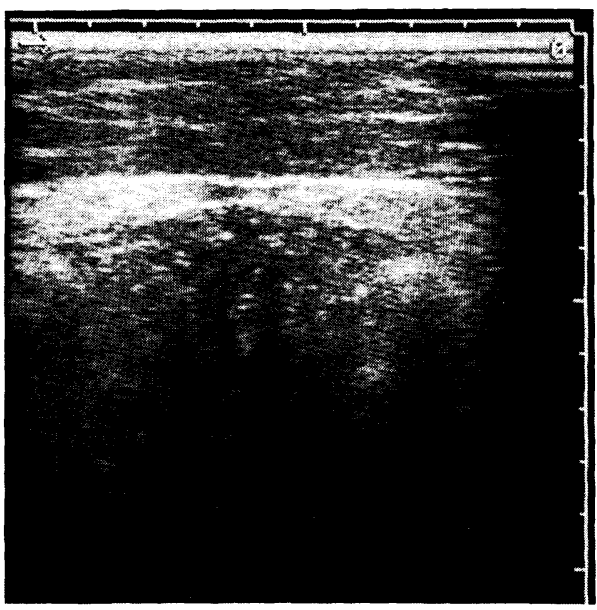

Fig. 4. An image of multiple strata in subcutaneous fat tissue of abdomen.

2) Plural echoes in the subcutaneous fat layer: Sometimes more than two relatively strong echoes appeared from a shallower layer. Sites at which plural echoes frequently appeared were umbilicus, abdomen (Fig. 4), iliac crest, trochanter and buttock. HAYMES et al. (1976) studied abdomen, iliac crest, subscapular and triceps sites by the A-mode ultrasonic method and found plural echoes from interfaces in the fat layer on the iliac crest. Using X-ray computed tomography, MATSUYAMA et al. (1984) observed double strata of the subcutaneous fat on the trunk of adult males and females. It is important to discriminate the fascia from these interfaces contained in the fat.

3) The dead time region and other problems: A "dead time region" is created by a lowering of receiver sensitivity just after the transmission of an ultrasonic pulse (KIKUCHI, 1980). If the subcutaneous fat layer is thinner than several millimeters, it can be lost to observation in this region. At a site such as the ankle, where the fat layer was often thinner than the depth of the dead time region, it was difficult to observe the

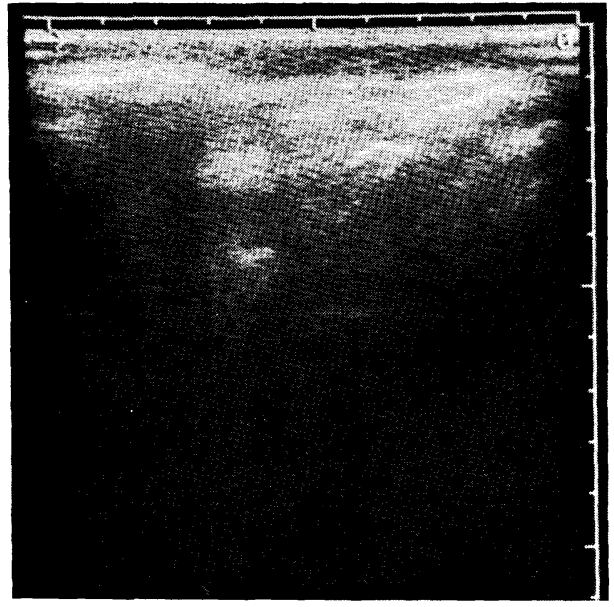

Fig. 5. Image at the cheek, where no strong reflection indicating the fat-muscle interface can be identified.

Table 1. Accessibility of B-mode ultrasonic measurement of subcutaneous fat thickness to 22 body sites*

\begin{tabular}{lrcc}
\hline \multirow{2}{*}{ sites } & \multicolumn{3}{c}{ accessibility } \\
\cline { 2 - 4 } & easy & $\begin{array}{l}\text { moderately } \\
\text { difficult }\end{array}$ & difficult \\
\hline 1. Anterior chest & 55 & 3 & 0 \\
2. Anterior axilla & 58 & 0 & 0 \\
3. Umbilicus & 55 & 3 & 0 \\
4. Abdomen & 58 & 0 & 0 \\
5. Lateral chest & 58 & 0 & 0 \\
6. Iliac crest & 57 & 1 & 0 \\
7. Posterior waist & 58 & 0 & 0 \\
8. Trochanter & 51 & 7 & 0 \\
9. Posterior neck & 0 & 0 & 58 \\
10. Subscapular & 54 & 4 & 0 \\
11. Posterior sulcus & 0 & 55 & 3 \\
12. Buttock & 54 & 4 & 0 \\
13. Triceps & 45 & 13 & 0 \\
14. Lateral forearm & 58 & 0 & 0 \\
15. Wrist & 0 & 58 & 0 \\
16. Anterior thigh & 54 & 4 & 0 \\
17. Medial thigh & 58 & 0 & 0 \\
18. Lateral calf & 58 & 0 & 0 \\
19. Medial calf & 58 & 0 & 0 \\
20. Ankle & 0 & 2 & 56 \\
21. Cheek & 0 & 0 & 58 \\
22. Chin & 0 & 0 & 58 \\
\hline * Figures & & 0 & \\
\hline
\end{tabular}

* Figures indicate number of cases observed

Fig. 6-1. Typical images of the sites which are easy to access. The arrows in each image indicate the boundary of the subcutaneous tissue. 


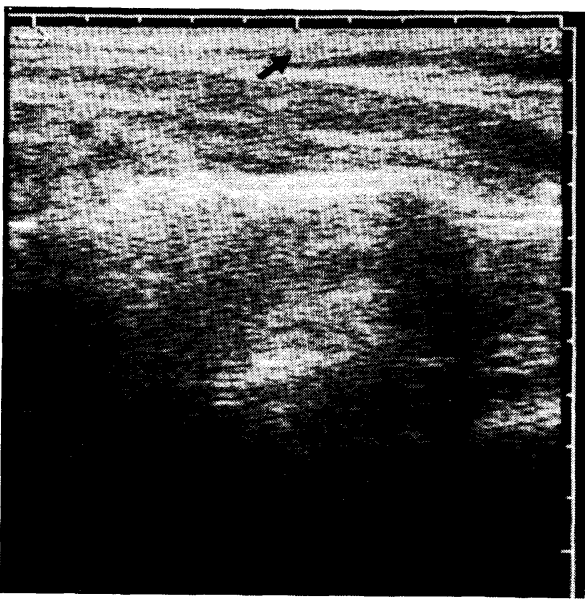

Anterior chest

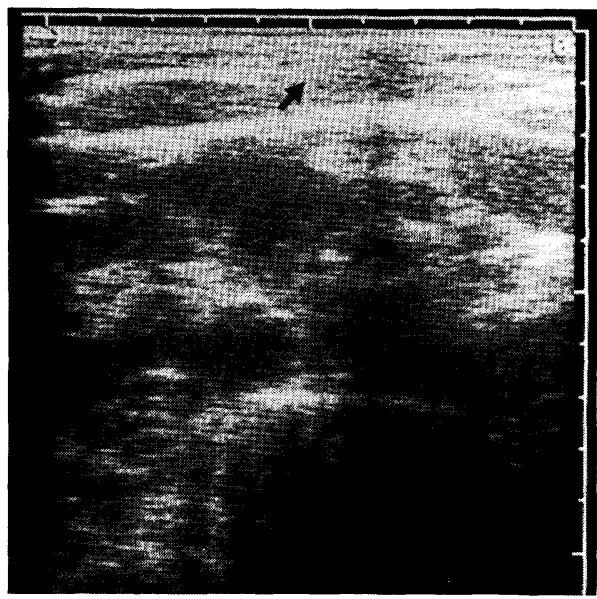

Umbilicus

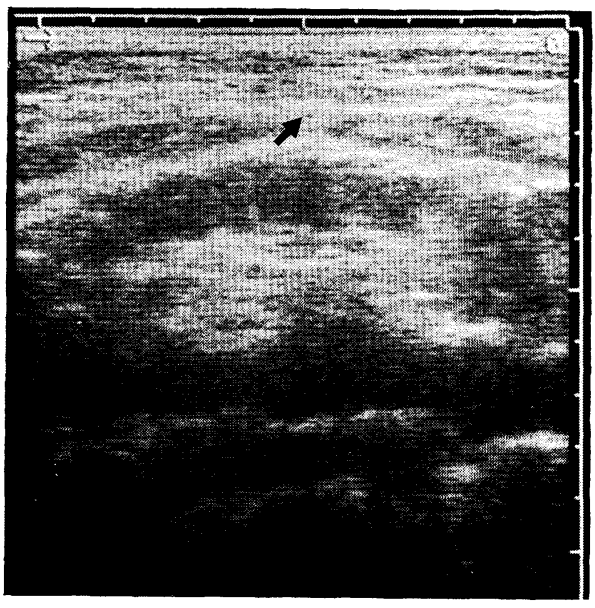

Abdomen

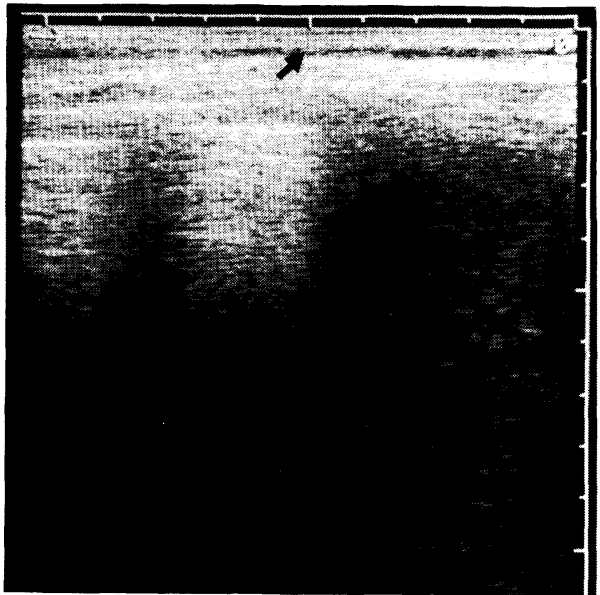

Lateral chest

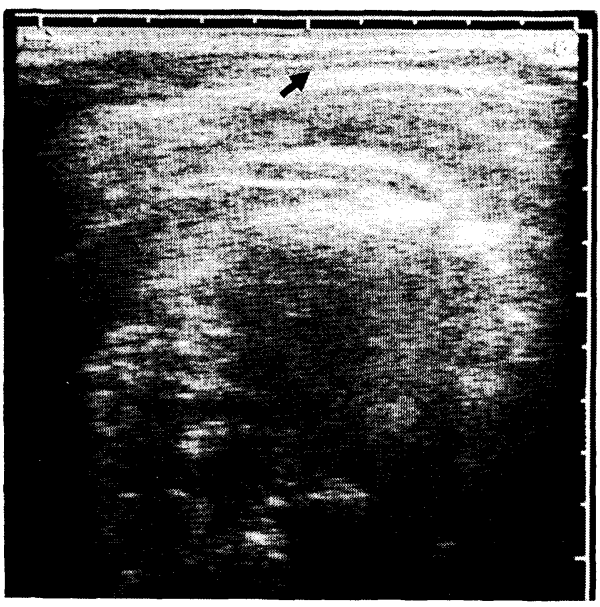

Iliac crest

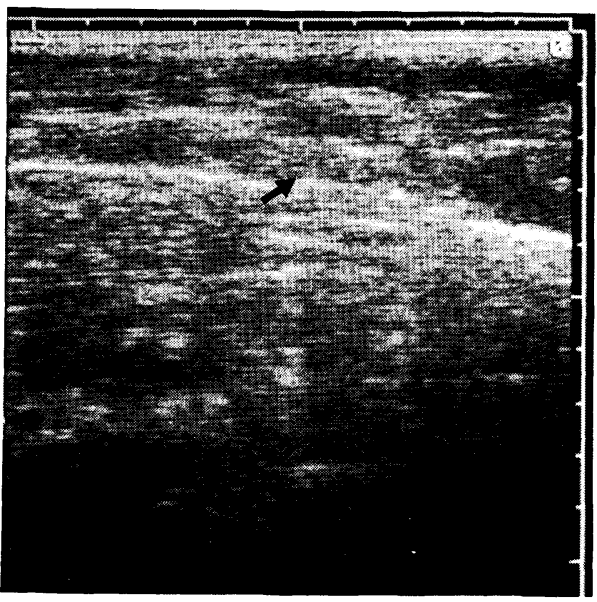

Buttock 
boundary of the fat layer. For such site, probing using a gelatinous stand-off is preferable. On the cheek (Fig. 5) and the chin, no intense echo showing the boundary of the fat layer was detected. For a site such as the posterior sulcus, where the subcutaneous fat was relatively thin and accompanied by stiff connective tissue, which reflects a strong wave, it was difficult to identify

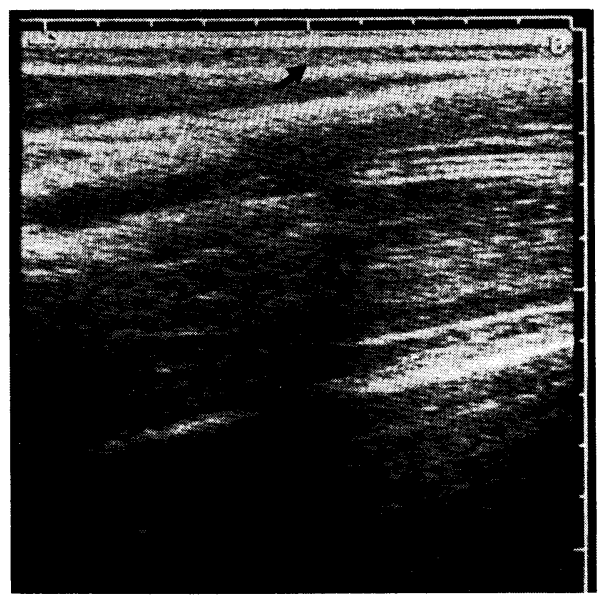

Lateral forearm

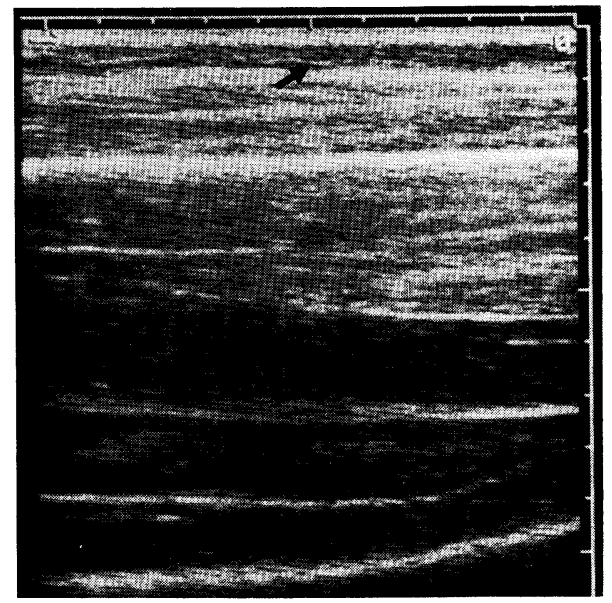

Lateral calf the boundary.

\section{How to discriminate the boundary}

An image of muscle contracting and relaxing provided a useful clue for discriminating the fascia, especially for triceps. When contact pressure of an ultrasonic probe is increased, the layers are compressed. Reduction of thickness

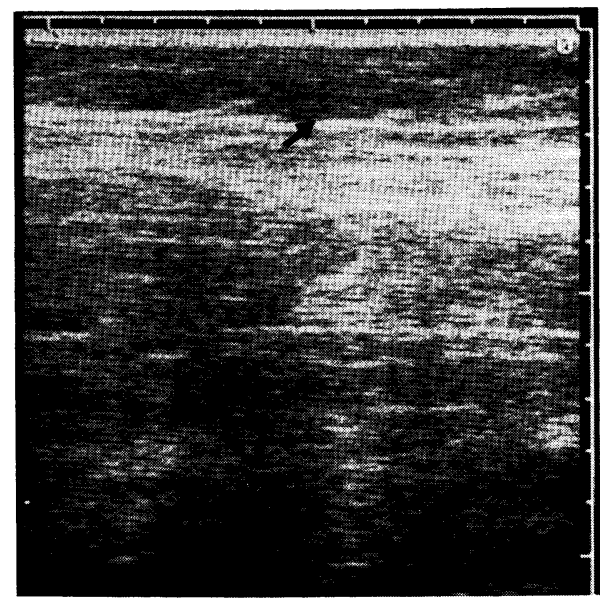

Medial thigh

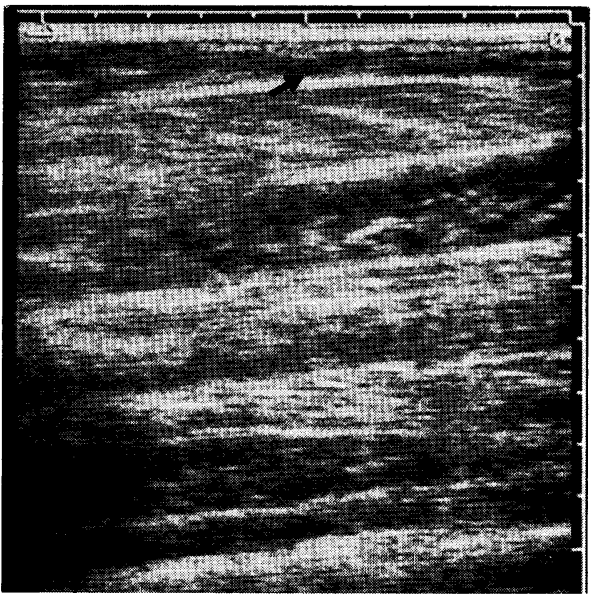

Medial calf

Fig. 6-2. Typical images of the sites which are easy to access (continued).

Fig. 7-1. Typical images of the 7 sites which are moderately difficult to access. The arrows in each image indicate the boundary of the subcutaneous tissue. 


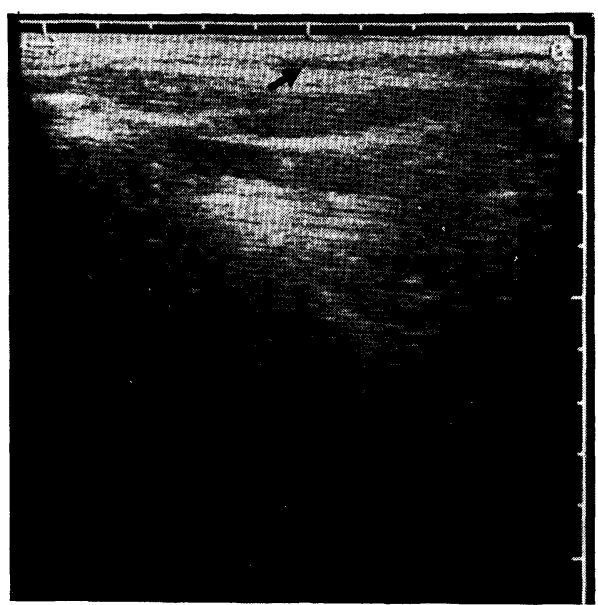

Anterior axilla

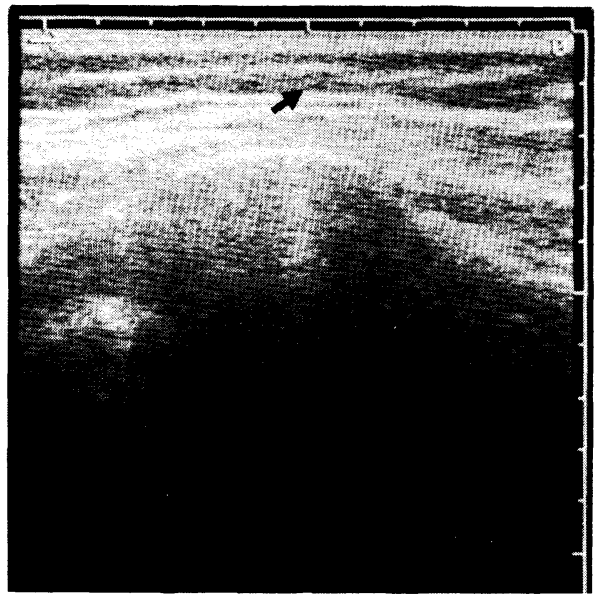

Trochanter

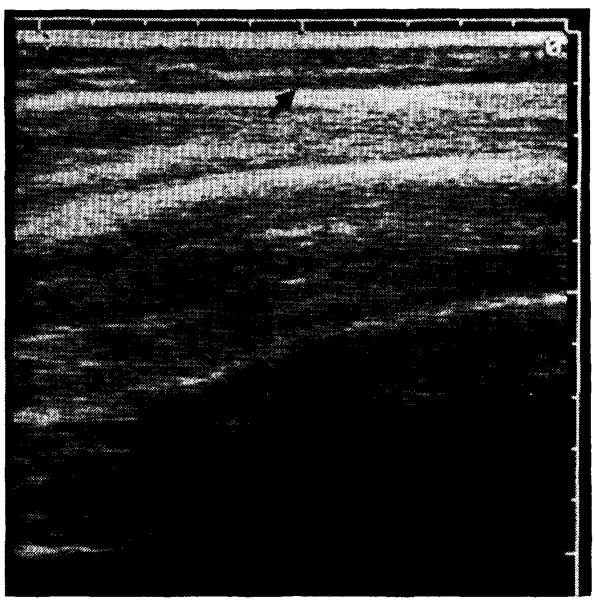

Triceps

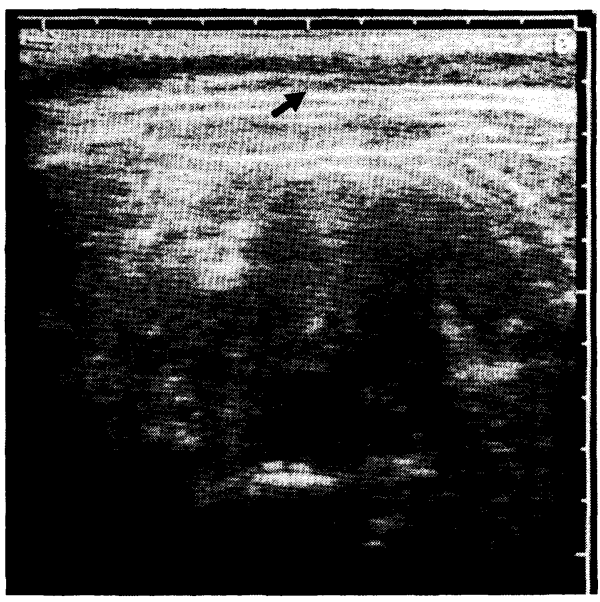

Posterior waist

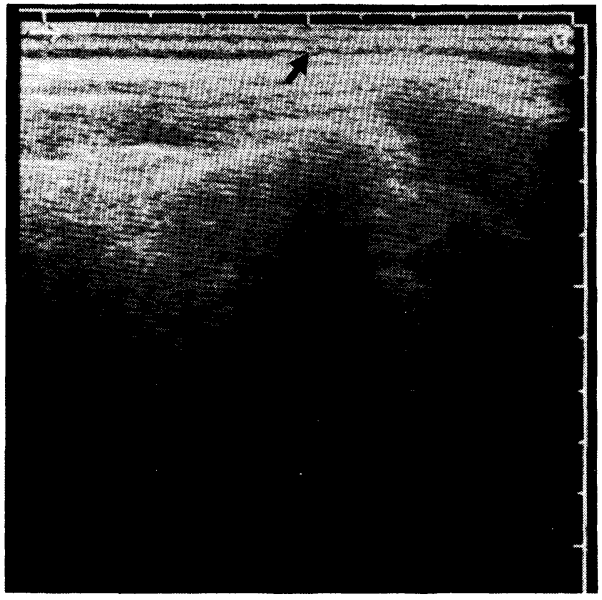

Subscapular

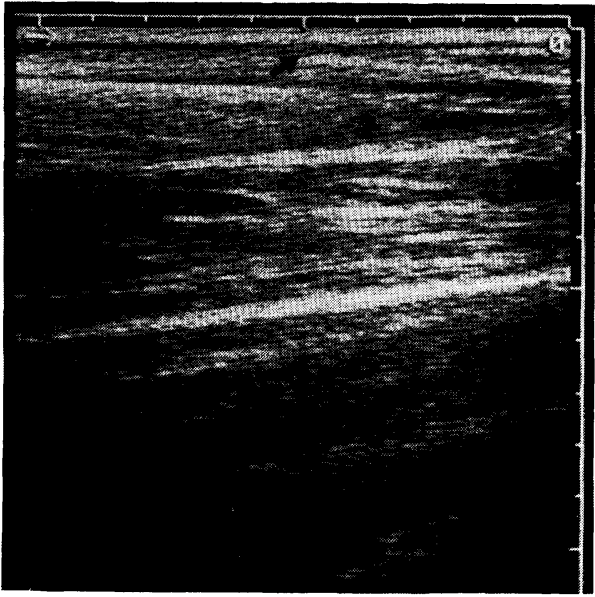

$--\cdot$ 
seems to differ between fat and muscle. Pressing on the measuring site is helpful for sites including the anterior chest, anterior axilla, trochanter, triceps, and wrist. Consequently, presence of the individual differences in the tomographic image and the plural echoes did not necessarily prevent the correct identification of the subcutaneous fat layer by a trained person.

\section{Accessibility of measuring sites}

From the above observations, 22 sites were classified into three groups in accordance with the degree of accessibility to measurement. Table 1 shows the results of the examinations of the accessibility.

Group A: Sites which permitted easy and stable measurement. The ten sites included were the anterior chest, umbilicus, abdomen, lateral chest, iliac crest, buttock, lateral forearm, medial thigh, lateral calf, and medial calf.

Group B: Sites at which measurement is possible but moderately difficult. For the seven sites which were the anterior axilla, posterior waist, subscapular, trochanter, triceps, wrist, and anterior thigh, measurement should be done by

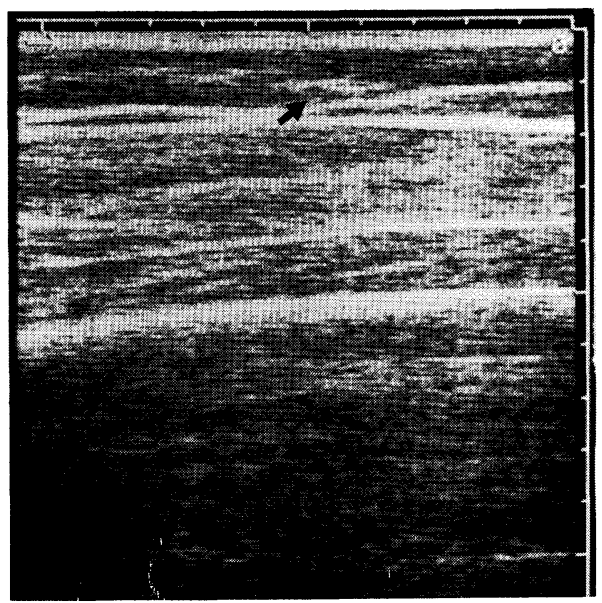

Anterior thigh

Fig. 7-2. Typical image of the sites which are moderately difficult to access (continued). a trained person. For ankle site, probing using a stand-off was preferable.

Group C: Sites at which measurement is difficult. The four sites included were the posterior neck, posterior sulcus, cheek, and chin.

Figs. 6-1 to 7-2 show sample tomograms of the seventeen sites confirmed to be measurable (groups A and B). The A and B groups included sites such as the buttock and thigh, where measurement of subcutaneous fat thickness was often difficult by skinfold method but is indispensable for obtaining apparent characteristics and obesity/leanness as a basis for the designing of comfortable clothing.

\section{抄 録}

全身 22 部位における B モード超音波法測定による皮 下脂肪層の同定

松山 容子・植竹 桃子・垣内美奈子 植竹 種美·柳澤 澄子·近藤 四郎

全身の皮下脂肪分布に関する情報は，着心地のよい， 体にあった衣服の設計条件を追求するためには重要な ものである。 そこで本研究では，医療用 B モード超音 波法による皮下脂肪厚測定を, 人体の多様な部位に適 用する場合の，測定部位同定について検討した，すな わち，同定を困難にしている，(1)断層像個人差，(2)脂肪 組織から反射される複数のエコー, (3)受信機の過渡現 象などの問題について, 若年成人女子 58 名を被検者と L, 上胸部, 腋前面, 臍側部, 下腹部, 側胸部, 腸稜部, 腰背部，大転子，局甲下角，殿部，上腕後面，前腕外 側, 手首, 大腿前面, 大腿内側, 下腿外側, 下腿内側, 足首, 煩骨部, オトガイ部, 頝椎部, 胸椎部の 22 部位 について検討し, 測定のしやすさに従って分類した.こ こに掲げた 22 部位のうち, 前者 18 部位では, 皮下脂 肪層の同定が可能であると確認されたが, 後者 4 部位 では確実な同定は困難であった，前者には，衣服設計 の観点から不可欠であるにもかかわらず従来の方法で は測定の困難な部位が含まれているので, 今後貴重な データが得られることになろう。 


\section{References}

BORKAN, G.A., D.A. HULTS, J. CARDARElli and B.A. BURROWS, 1982: Comparison of ultrasound and skinfold measurements in assessment of subcutaneous and total fatness. Am. J. Phys. Anthropol., 58: $307-313$.

FANELLI, M.T., R.J. KUCZMARSKI, 1984: Ultrasound as an approach to assessing body composition. Am. J. Clin. Nutr., 39: 703-709.

HAYMES, E.M., H.M. LUNDEGREN, J.L. LOOMIS and E.R. BUSKIRK, 1976: Validity of the ultrasonic technique as a method of measuring subcutaneous adipose tissue. Ann. Hum. Biol., 3: 245-251.

HimeS, J.H., A.F. ROCHE and R.M. SIERVOGEL, 1979: Compressibility of skinfolds and the measurement of subcutaneous fatness. Am. J. Clin. Nutr., 32: $1734-1740$

IKAI, M. and T. FUKUNAGA, 1968: Studies on body composition III - Investigation of body composition by ultrasound. Taiiku no Kagaku, 18: 71-76. (In Japanese)

[猪飼道夫・福永哲夫, 1968：身体組成の研究 III-超 音波による身体組成の分析一. 体育の科学, 18:7176. ]

IKAI, M., T. FUKUNAGA and H. TOHEDA, 1969: Studies on body composition of Japanese youth By ultrasound method and by specific gravity method. Bulletin of Faculty of Education, University of Tokyo, 11: 1-29. (In Japanese)

[猪飼道夫 - 福永哲夫 - 藤平田英彦, 1969：日本人青 少年の身体組成の研究-超音波法と比重法によるー。 東京大学教育学部紀要, 11:1-29.]

ISHII, T., 1986: Correlations between echolevel and histology of the fat tissue structure. J. Yonago Med. Ass., 33: 323-332. (In Japanese with English summary)

JONES, P.R.M., P.S.W. DAVIES and N.G. NORGAN, 1986: Ultrasonic measurement of subcutaneous adipose tissue thickness in man. Am. J. Phys. Anthropol., 71: 359-363.
KATCH, F.I., 1984: Individual differences of ultrasound assessment of subcutaneous fat: Effects of body position. Hum. Biol., 55: 789-795.

KATSUKI, S., H. SIBAYAMA, M. IKAI and S. KONDO, 1965: An ultrasonic apparatus for measurement of body composition. Bull. Phys. Fit. Res. Inst., 4: 34-41. (In Japanese)

[勝木新次 · 芝山秀太郎 · 猪飼道夫 · 近藤四郎, 1965 : 超音波による body composition 測定装置. 体力研 究, 4:34-41.]

KIKUCHI, Y., 1980: Ultrasound Medicine. Ed., Association for Ultrasound Medicine, Igaku Shoin, Tokyo, p.101. (In Japanese)

[菊池喜充, 1980：超音波医学会編, 超音波医学(分 担執筆). [医学書院, 101 頁]

KUCZMARSKI, R.J., M.T. FANELLI and G.G. KOCH, 1987: Ultrasonic assessment of body composition in obese adults: Overcoming the limitations of the skinfold calipers. Am. J. Clin. Nutr., 45: 717-724.

MATSUMOTO, H., S. INOKUCHI and Y. SAWADA, 1985: Comparisons of ultrasonic apparatus and caliper in measuring skinfold thickness of school children. J. Anthrop. Soc. Nippon, 93: 439-445.

MATSUYAMA, Y., S. INOKUCHI and M. SUZUKI, 1984: Observation of the hypodermic fatty layer of the human torso by computed tomography method. Showa Igakukai Zasshi, 44: 61-73. (In Japanese with English summary)

TOYOKAWA, H., N. KIMURA and E. MURAI, 1984a: Studies for the practical uses of the A-mode type ultrasonic device. (The first report). Validity in identification of the target wave at thigh. Nihon Koushuu Eisei Zasshi, 31: 14-20. (In Japanese with English summary)

TOYOKAWA, H., N. KIMURA and E. MURAI, 1984b: Studies for the practical uses of the A-mode type ultrasonic device. Stability of measurement at upperarm posterior. J. Japanese Health and Human Ecology, 50: 197-204. (In Japanese with English summary).

\section{松山容子 \\ 大妻女子大学家政学部被服学科 \\ 下102 東京都千代田区三番町 12}

Yoko MATSUYAMA

Faculty of Home Economics, Otsuma Women's University

12 Sanban-cho, Chiyoda-ku, Tokyo 102, Japan 